Nig. J. Biotech. Vol. 38 (2) : 24-39 (Dec 2021)

ISSN: 01891731

Available online at

http://www.ajol.info/index.php/njb/index

and www.biotechsocietynigeria.org

DOI: https://dx.doi.org/10.4314/njb.v38i2.3

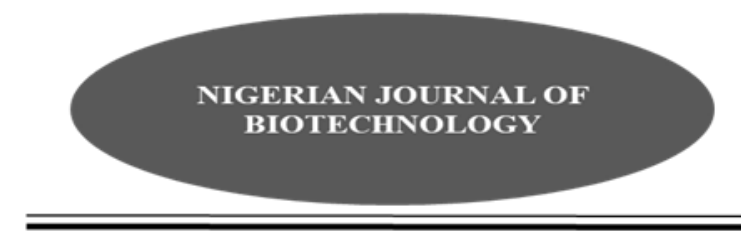

\title{
Quality Assessment of Strips produced from Soybean and Cassava Flour Blends
}

\author{
${ }^{1 *}$ Onwuzuruike, U. A., ${ }^{1}$ Okakpu, K. G., ${ }^{1}$ Ndife, J., ${ }^{1}$ Uzochukwu, U. C. and ${ }^{1}$ Abiamere, \\ E. U. \\ ${ }^{1}$ Department of Food Science and Technology, College of Applied Food Sciences and Tourism, Michael Okpara \\ University of Agriculture, Umudike, Abia State, Nigeria.
}

\begin{abstract}
This study evaluated the quality characteristics of strips produced from blends (\%) of soybean and cassava flours. Wholesome cassava roots and soybean grains were procured and processed into flours. Seven blends of soybean and cassava flour blends were formulated (0:100, 100:0, 50:50, 40:60, 20:80, 60:40 and 80:20) while 100\% wheat flour served as control. Strips were produced from the blends. The composite flours were analyzed for their functional properties while the proximate, mineral, vitamin, antinutrient contents and sensory characteristics (assessed by 25 panelists) of the strips were assessed. The statistical analysis was carried out using one-way ANOVA at $95 \%$ confidence level. The functional properties ranged from 0.53 to $0.77 \mathrm{~g} / \mathrm{mL}$ for bulk density, 3.76 to $12.88 \%$ for foam capacity, 1.92 to $49.00 \%$ for foam stability, 108.00 to 204.00 $\mathrm{g} / \mathrm{mL}$ for oil absorption capacity, 81.00 to $140.50 \mathrm{~g} / \mathrm{mL}$ for water absorption capacity and 61.07 to $87.00^{\circ} \mathrm{C}$ for gelatinization temperature. The results of proximate analysis ranged from 1.44 to $3.46 \%$ for moisture, 1.63 to $3.91 \%$ for ash, 2.04 to $10.76 \%$ for fat, 0.18 to $1.37 \%$ for crude fibre, 4.07 to $24.16 \%$ for protein and 60.46 to $88.10 \%$ for carbohydrate. The phytate, tannin, trypsin inhibitor, saponin and hydrogen cyanide ranged from 0.22 to $5.59 \mathrm{mg} / 100 \mathrm{~g}, 0.34$ to 4.13 $\mathrm{mg} / 100 \mathrm{~g}, 0.04$ to $1.69 \mathrm{mg} / 100 \mathrm{~g}, 0.02$ to $0.36 \mathrm{mg} / 100 \mathrm{~g}$ and 0.00 to $2.11 \mathrm{mg} / 100 \mathrm{~g}$ respectively. Sensory analysis revealed that $80 \%$ soybean flour and $20 \%$ cassava flour possessed better organoleptic characteristics. Production of strips from blends of soybean and cassava flours improved the nutrient composition, sensory properties with acceptable/safe antinutrient limit which can be optimized for value addition.
\end{abstract}

Keywords: Quality, Soybean, Cassava, Strips, Sensory Characteristics.

*Corresponding author's Email: onwuzuruike.uzochukwu@mouau.edu.ng, Telephone: +234 (0) 8033981164

Introduction

Composite flours are a mixture of flours from tubers rich in starch (e.g. cassava, yam, sweet potato) and/or protein-rich flours (e.g. soy, peanut) and/or cereals (e.g. maize, rice, millet, buckwheat), with or without wheat flour. The supplementation of cereal flour with inexpensive stable food such as legume/pulses helps in improving the nutritional quality of cereal products (Suresh et al., 2015). The use of composite flour for commercial snack making purposes are increasingly gaining much attention in Nigeria (Shittu et al., 2007). The use of composite flours has the following advantages: savings of hard currency, a better supply of protein for human nutrition and a simple production technology (Bugusu et al., 2001) aside the fact that wheat cannot be economically produced in tropical countries like Nigeria due to unfavourable climatic conditions. For these reasons, local staples like soybean and cassava are currently being investigated as industrial raw materials in confectionaries production.

The wide use of soybean (Glycine max) in food production could be due to the fact that, it is a cheap source of protein that provides similar quality of protein as meat, milk and eggs (Kusuma, 2015). Soybean contains $37.69 \%$ protein, $28.20 \%$ fat and $16.31 \%$ carbohydrate (Etiosa et al., 2018). It is 
also rich in isoflavones which have numerous health benefits such as lowering of blood cholesterol level, cancer prevention and reduction of risk of heart diseases (Kusuma, 2015). It can be processed into a wide variety of food products, including edible oil, milk, tempeh, infant formula and flour (O'Keefe et al., 2015). Flour from whole soybean seeds has huge potentials of being used to enrich foods in order to help individuals meet recommended daily intake of nutrients such as protein (Adelakun et al., 2013). Pele et al. (2016) reported that soybean flour has protein ( 23.98 to $28.44 \%$ ), carbohydrate (38.48 to $43.52 \%$ ), fat ( 20.51 to $26.20 \%$ ) and reduced anti-nutrient factors than the unprocessed seeds.

Cassava (Manihot esculenta, Crantz) is a food security crop with the capacity of addressing some health-related problems such as ketosis (Onyenwoke and Simonyan, 2014). The starch content varies between 60.34 to $86.79 \%$ of the mass of white-flesh cassava and $69.90 \%$ of biofortified yellow-flesh cassava (Ayetigbo et al., 2018). Cassava root of 0.50 to $2.50 \mathrm{~kg}$ have 0.30 to $3.50 \%$ protein, 0.03 to $0.50 \%$ lipids, 0.10 to 3.70 $\%$ dietary fibre, 0.40 to $1.70 \%$ ash, 0.03 to 0.28 $\mathrm{mg} / 100 \mathrm{~g}$ thiamin, 0.03 to $0.06 \mathrm{mg} / 100 \mathrm{~g}$ riboflavin, 19.00 to $176.00 \mathrm{mg} / 100 \mathrm{~g}$ calcium, 0.30 to 1.40 $\mathrm{mg} / 100 \mathrm{~g}$ iron and 6.00 to $152.00 \mathrm{mg} / 100 \mathrm{~g}$ of phosphorus (Omosuli, 2018).

The increasing urbanization has profoundly contributed to the popularity, increased production and consumption of snacks. The possible exploration of non-wheat flours in snack production could possibly increase the use of home grown crops. Vitamin A deficiency which is responsible for visual impairment is a rising health concern in developing countries. Indigenous crops such as carotenoid rich cassava roots could contribute to its eradication. More so, protein energy malnutrition (PEM) which arises as a result of insufficient consumption of protein and energy is known to result in high rate of death particularly among children. Economically, the continuous production of snacks using imported wheat flour would continue to affect Nigeria's foreign exchange negatively. Production of strips from flour blends of cassava and soybean will reduce the over dependence on wheat flour for snack production, improve farmer's livelihood, create variety, contribute in combating protein energy malnutrition and vitamin $A$ deficiency, make strips affordable and increase the demand of soybean and cassava for food development. This study is therefore aimed at producing and evaluating strips from blends of cassava and soybean flours and finding alternative ways of exploiting the industrial potential and nutritional benefits of cassava and soybean.

\section{Materials and methods Sources of raw materials}

The cassava roots (Manihot esculenta Crantz) (UMUCASS 38 (TMS 01/1371) variety) used for this study was procured from National Root Crops Research Institute Umudike, Abia State. Soybean seeds (Glycine max) and other ingredients such as onion, salt and vegetable oil were procured from Ubani local market, Umuahia, Abia State.

\section{Sample preparation Production of cassava Flour}

The method described by Alozie and Chinma (2015) was employed in cassava flour production. Cassava roots were sorted, cleaned, manually peeled and sliced prior to oven drying at $60^{\circ} \mathrm{C}$ for $9 \mathrm{~h}$. The oven dried cassava roots were milled using attrition mill (Model SK-30-SS, USA) and sieved through $500 \mu \mathrm{m}$ mesh size to obtain the cassava flour which was packaged in polyethylene bag prior to further use. Processing of soybean seeds into soybean flour The method of Adelakun et al. (2013) was used in processing of soybeans into flour with modification. Soybean seeds were sorted to remove stone and unwholesome seeds and were cleaned properly. The seeds were steeped in clean tap water for $6 \mathrm{~h}$, drained and boiled in water for 30 min, cooled and manually dehulled. The dehulled soybean seeds were washed in water, drained, dried at $60^{\circ} \mathrm{C}$ for 6 h, milled ( Attrition mill Model SK-30-SS, USA), sieved through $500 \mu \mathrm{m}$ mesh size and packaged for further use.

\section{Formulation of soybean-cassava composite flour}

The proportion of soybean flour (SF) and cassava flour (CF) used in the formulation of composite flour were as follows; 0:100 (SF100), 100:0 (CF100), 50:50 (SF50:CF50), 40:60 (SF40:CF60), 20:80 (SF20:CF80), 60:40 (SF60:CF40) and 80:20 (SF80:CF20), while $100 \%$ wheat flour (WF100) served as control.

\section{Functional analysis}

The method described by Onwuka (2018) was used in the determination of bulk density, gelatinization temperature, water absorption capacity, oil 
absorption capacity, foam capacity and stability and wettability of the flour samples.

\section{Production of soybean-cassava strips}

Strips were produced according to the procedure of Dada et al. (2017) (Figure 1). The recipe for the production of soybean-cassava strips comprised wheat flour $(100 \mathrm{~g})$, cassava flour $(350 \mathrm{~g})$, soybean flour $(350 \mathrm{~g})$, onion $(360 \mathrm{~g})$, salt $(40 \mathrm{~g})$, water $(1200 \mathrm{~mL})$ and vegetable oil $(3000 \mathrm{~mL})$.

\section{Sample analyses}

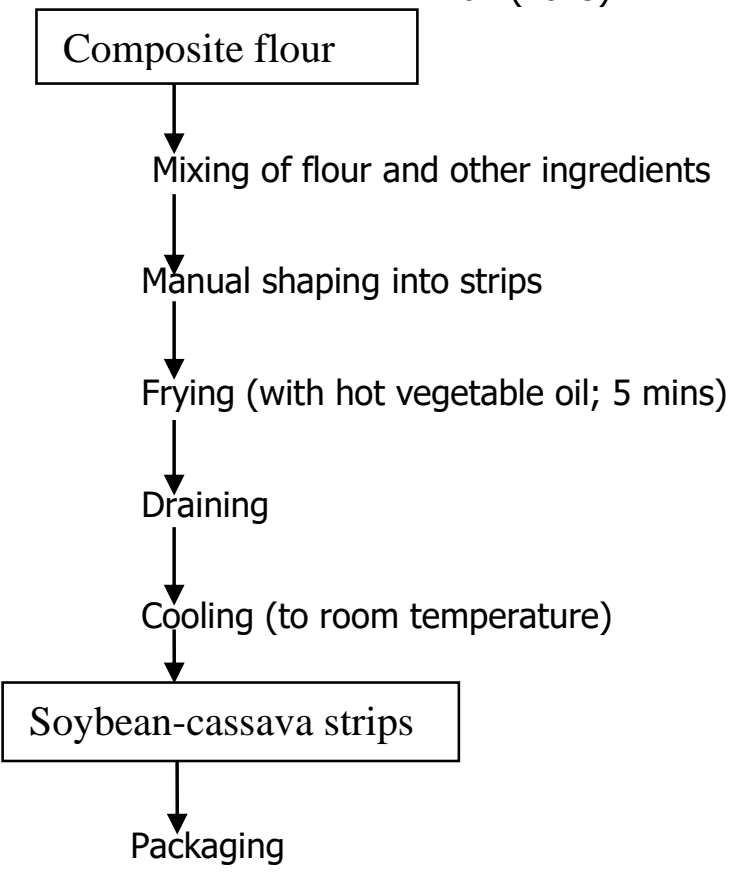

\section{Proximate analysis}

The method of AOAC (2010) was used in determining the proximate composition including moisture, crude protein, crude fibre, ash, fat and carbohydrate contents.

Vitamin analysis: The spectrophotometric method described by Onwuka (2018) was employed in the determination of vitamin $A$, vitamin $B_{1}$, vitamin $B_{2}$, vitamin $B_{3}$ while the vitamin $C$ content was analyzed according to the method described by Achikanu et al. (2013).

Fig 1: Production of soybean-cassava flour blends.

\section{Mineral analysis}

The soybean-cassava strips were analyzed for potassium and iron content using Achikanu et al. (2013) procedure. Zinc, calcium, magnesium, phosphorous contents were determined according to the method described by Onwuka (2018). Sodium content of the soybean-cassava strips was determined using the flame photometric method of AOAC (2010).

\section{Antinutrient analysis}

Nwosu (2011) spectrophotometric procedure was adopted in analyzing for trypsin inhibitor and tannin contents of the soybean-cassava strips. Hydrogen cyanide was determined according to the procedure described by Onwuka (2018). The saponin and phytate contents were respectively determined using the colorimetric and spectrophotometric methods of AOAC (2010).

\section{Sensory analysis}

The method described by Iwe (2014), was used for evaluating the sensory attributes of the soybeancassava strips. The appearance, taste, aroma, texture, mouthfeel and general acceptability of the soybean-cassava strips were evaluated by 20 member semi-trained panelists randomly selected from students of Department of Food Science and Technology, Michael Okpara University of Agriculture, Umudike, Abia State. The samples were presented in identical packaging materials labeled with appropriate codes. Portable water was served to the panelists for mouth rinsing after each tasting to avoid interference with the taste of the succeeding samples. Sensory attributes of the soybean-cassava strips were scored on a 9-point 
Hedonic scale ranging from like extremely (9) to dislike extremely (1).

\begin{abstract}
Statistical Analysis
The data obtained from laboratory experiment were expressed as mean \pm SD (standard deviation) of duplicate determinations. One-way ANOVA was used to analyze the experimental data. When a significant difference exists among the means level of significance among the means was compared using Duncan Multiple Range Test method at $95 \%$ confidence level (SPSS, 2018).
\end{abstract}

\section{Results and Discussions}

\section{Functional properties of soybean-cassava flour blends}

Table 1 showed the functional properties of soybean-cassava flour blends. The bulk density (BD) $(0.53$ to $0.77 \mathrm{~g} / \mathrm{mL})$ obtained in this study was lower than the values $(0.76$ to $0.82 \mathrm{~g} / \mathrm{mL}$ ) reported by Suresh et al. (2015) for cassava-wheat composite flour. The highest BD $(0.77 \mathrm{~g} / \mathrm{mL})$ was recorded in $100 \%$ cassava flour (CF100) while SF50:CF50 had the lowest BD $(0.53 \mathrm{~g} / \mathrm{mL})$. BD is defined as the mass/volume of a substance. It is important in assessing the load carrying capacity of a packaging material (Ezeocha and Onwuka, 2010). Suresh et al. (2015) reported that BD is dependent on the particle size, starch, and initial moisture content of flour. The BD obtained in this study is considerably low which might suggest their suitability in food formulation with an extra advantage in the formulation of complimentary foods (Akapata and Akubor, 1999) and may possibly encourage bulk packing of the flour samples using compact packaging material (Ezeocha and Onwuka, 2010).

The foam capacity (FC) of the flour blends ranged from 3.76 to $12.88 \%$. The reduction of soybean flour and increase in cassava flour resulted into decrease in the FC of the flour blends. The results implied that legumes have higher ability to form foam than root crops. Legumes are rich in protein and may likely form foam than root crops because of their higher protein content since foam capacity is the extent to which protein dispersion in water form foam. Onimawo and Akubor (2005) reported that the texture of food products can be improved by foam, although the method of processing, pest infestation as well as contamination of the food material can affect the ability of the food material to form foam. Kaushal et al. (2012) reported that legumes influence the formation of foams positively by reducing the surface tension of the barrier at the water-air interface, thus, a cohesive thin film was formed around the air bubbles. Consequently, higher legume-containing composite flours might have a better foam performance when used in formulating food materials that require foam formation.

Foam stability (FS) of the flours ranged from 1.92 to $49.00 \%$, showing significant difference $(p<0.05)$ among the flour samples. As the proportion of soybean flour decreased and cassava flour increased in the flour blends, the FS decreased concurrently. This observation could be attributed to the low surface tensions and high viscosity that exist at the surface of colloidal solutions, forming a tough amorphous solid surface film (Mwasaru et al., 1999). Low FS in flours can be attributed to inadequate electrostatic repulsions resulting from low protein availability as well as lesser solubility and to protein denaturation (Butt and Batool, 2010). Good FS are desirable attributes for flours intended for the production of a variety of baked products such as angel cakes, cookies, akara, etc and also act as functional agents in other food formulations (El-Adawy, 2001). The FS obtained in this study for the composite flours are quite high which implied that the flour blends may be useful as aerating agents in food productions (Hung et al., 2004) (such as cakes and other baked products) that require the production of foam.

The oil absorption capacity (OAC) (108.00 to 204.00 $\mathrm{g} / \mathrm{mL}$ ) was higher than 130.00 to $156.00 \mathrm{~g} / \mathrm{mL}$ reported by Suresh et al. (2015) for cassava-wheat composite flour. The composite flours had lower $O A C$ values than the reference sample. Increasing the proportion of soybean flour, increased the OAC of the flour samples which indicated that legumes might have better OAC. However, the OAC of the flour samples were generally high and differ significantly $(p<0.05)$ from each other. OAC is an index of flour protein capacity to bind fat (Onimawo and Akubor, 2005). The protein content, physical nature of the oil as well as the type of method used may have affected the oil absorption capacity of the samples leading to variation (Ibeabuchi et al., 2017). The high OAC obtained for the flour blends might translate to good applicative potential in food formulations since high OAC increases the retention 
Onwuzurike et al. / Nig. J. Biotech. Vol. 38 Num. 2 : 24-39 (December 2021)

of flavor, and also increases the mouth feel of products. Although, the high OAC of the flour blends might be challenging with respect to shelf life particularly in bakery products (Adebowale and Lawal, 2004). 
Table 1: Functional properties of soybean-cassava flour blends.

\begin{tabular}{lllllll}
\hline Samples & $\mathrm{BD}(\mathrm{g} / \mathrm{mL})$ & $\mathrm{FC}(\%)$ & $\mathrm{FS}(\%)$ & $\mathrm{OAC}(\mathrm{g} / \mathrm{mL})$ & $\mathrm{WAC}(\mathrm{g} / \mathrm{mL})$ & $\left.\mathrm{GT}^{\circ} \mathrm{(}\right)$ \\
\hline WF100 & $0.56^{\mathrm{cd}} \pm 0.01$ & $7.15^{\mathrm{d}} \pm 0.21$ & $49.00^{\mathrm{a}} \pm 2.80$ & $204.00^{\mathrm{a}} \pm 1.01$ & $140.50^{\mathrm{a}} \pm 0.01$ & $61.07^{\mathrm{f}} \pm 0.01$ \\
SF100 & $0.63^{\mathrm{b}} \pm 0.01$ & $12.88^{\mathrm{a}} \pm 0.21$ & $24.00^{\mathrm{b}} \pm 1.41$ & $108.00^{\mathrm{f}} \pm 1.04$ & $81.00^{\mathrm{f}} \pm 1.01$ & $87.00^{\mathrm{a}} \pm 1.01$ \\
CF100 & $0.77^{\mathrm{a}} \pm 0.01$ & $3.76^{\mathrm{g}} \pm 0.31$ & $1.92^{\mathrm{h}} \pm 0.03$ & $145.00^{\mathrm{c}} \pm 1.04$ & $140.50^{\mathrm{a}} \pm 0.01$ & $79.75^{\mathrm{e}} \pm 0.31$ \\
SF50:CF50 & $0.53^{\mathrm{e}} \pm 0.01$ & $7.09^{\mathrm{d}} \pm 0.01$ & $15.50^{\mathrm{e}} \pm 0.40$ & $121.00^{\mathrm{ed}} \pm 1.40$ & $126.00^{\mathrm{d}} \pm 1.04$ & $84.50^{\mathrm{c}} \pm 0.71$ \\
SF40:CF60 & $0.59^{\mathrm{c}} \pm 0.01$ & $6.00^{\mathrm{e}} \pm 0.10$ & $11.07^{\mathrm{f}} \pm 0.01$ & $118.50^{\mathrm{e}} \pm 0.10$ & $130.50^{\mathrm{c}} \pm 0.07$ & $83.50^{\mathrm{cd}} \pm 0.71$ \\
SF20:CF80 & $0.57^{\mathrm{cd}} \pm 0.01$ & $4.62^{\mathrm{f}} \pm 0.10$ & $7.82^{\mathrm{g}} \pm 0.10$ & $108.00^{\mathrm{f}} \pm 0.01$ & $135.50^{\mathrm{b}} \pm 0.04$ & $80.00^{\mathrm{d}} \pm 1.10$ \\
SF60:CF40 & $0.54^{\mathrm{ed}} \pm 0.01$ & $8.41^{\mathrm{c}} \pm 0.08$ & $18.33^{\mathrm{d}} \pm 0.20$ & $123.50^{\mathrm{d}} \pm 0.07$ & $124.00^{\mathrm{d}} \pm 1.01$ & $85.50^{\mathrm{bc}} \pm 0.11$ \\
SF80:CF20 & $0.56^{\mathrm{d}} \pm 0.01$ & $10.20^{\mathrm{b}} \pm 0.09$ & $21.43^{\mathrm{c}} \pm 0.03$ & $200.50^{\mathrm{b}} \pm 0.01$ & $103.50^{\mathrm{e}} \pm 0.07$ & $86.00^{\mathrm{ab}} \pm 1.41$ \\
\hline
\end{tabular}

Values are means \pm standard deviation of duplicate determination. Mean values in the same column with different superscripts are significantly different $(p<0.05)$. WAC-Water absorption capacity, OAC-Oil absorption capacity, FS-Foam Stability, FC-Foaming capacity, BD-Bulk density, GT-Gelatinization temperature. WF-Wheat flour, SF-Soybean flour, CF-Cassava flour. WF100 (100\% Wheat flour). SF100 ( $100 \%$ soybean flour). CF100 ( $100 \%$ cassava flour). SF50:CF50 ( $50 \%$ soybean flour: $50 \%$ cassava flour). SF40:CF60 (40\% soybean flour: $60 \%$ cassava flour). SF20:CF80 ( $20 \%$ soybean flour: $80 \%$ cassava flour). SF60:CF40 (60\% soybean flour: $40 \%$ cassava flour). SF80:CF20 ( $80 \%$ soybean flour: $20 \%$ cassava flour).

The water absorption capacity (WAC) (81.00 to $140.50 \mathrm{~g} / \mathrm{mL})$ differ significantly $(p<0.05)$ among the samples, which may be due to variation in the concentration of protein content, degree of association and conformational characteristics (Butt and Batool, 2010). The WAC of the flour blends decreased with increasing proportions of soybean flour, which indicated that cassava flour might have better WAC than soybean flour. Butt and Batool (2010) reported that protein possess both heads (hydrophilic and hydrophobic properties) which enables its association with moisture in foods. Adejuyitan et al. (2009) reported that carbohydrates also influence water absorption capacity of foods. The values of WAC for the composite flours were considerably high, which might be attributed to the presence of hydrophilic protein that has the capacity to bind water as well as high digestible starch. The values obtained in this study are desirable in flour and impliedly, legumes can be incorporated into food formulations involving other flours.

The gelatinization temperature (GT) of the flour blends ranged from 61.07 to $87.00^{\circ} \mathrm{C}$. The lowest GT was recorded for $100 \%$ wheat flour (WF100) which implied that WF100 took the shortest time to gelatinize, while soybean (a legume with high protein content) and cassava flour required higher temperature to gelatinize and consequently longer time. More so, composite flours containing higher proportion of cassava flour gelatinized at a lower temperature. GT is the temperature at which food material form gel or become gelatinous (Onwuka, 2010). The primary function of gel in foods is to bind or solidify the free water (Onimawo and Egbekun, 1998). The GT results obtained in this study are generally high and suggested that the flours could be suitable for the stabilization of emulsion in soups and cakes and other food formulations.

\section{Proximate composition}

Table 2 showed the proximate composition of soybean-cassava strips. The moisture content $(1.44$ to $3.46 \%)$ was generally low. The low moisture in the sample could be attributed to the frying process which has the capacity to extract almost all available free water. Hence, the strips might remain stable for a long period without spoilage at ambient temperature (Offor, 2015). 
Table 2: Proximate composition of the soybean-cassava strips.

\begin{tabular}{lllllll}
\hline Samples & $\begin{array}{l}\text { Moisture } \\
(\%)\end{array}$ & $\begin{array}{l}\text { Ash } \\
(\%)\end{array}$ & $\begin{array}{l}\text { Fat } \\
(\%)\end{array}$ & $\begin{array}{l}\text { Crude Fibre } \\
(\%)\end{array}$ & $\begin{array}{l}\text { Protein } \\
(\%)\end{array}$ & $\begin{array}{l}\text { Carbohydrate } \\
(\%)\end{array}$ \\
\hline WF100 & $2.61^{\mathrm{c}} \pm 0.02$ & $1.63^{\mathrm{f}} \pm 0.01$ & $4.51^{\mathrm{g}} \pm 0.01$ & $0.18^{\mathrm{b}} \pm 0.01$ & $9.71^{\mathrm{f}} \pm 0.02$ & $81.36^{\mathrm{b}} \pm 0.04$ \\
SF100 & $1.44^{\mathrm{g}} \pm 0.01$ & $2.91^{\mathrm{d}} \pm 0.01$ & $9.66^{\mathrm{b}} \pm 0.01$ & $1.37^{\mathrm{a}} \pm 0.01$ & $24.16^{\mathrm{a}} \pm 0.01$ & $60.46^{\mathrm{f}} \pm 0.00$ \\
CF100 & $2.16^{\mathrm{e}} \pm 0.01$ & $2.51^{\mathrm{e}} \pm 0.01$ & $2.04^{\mathrm{h}} \pm 0.01$ & $1.12^{\mathrm{ab}} \pm 0.01$ & $4.07^{\mathrm{g}} \pm 0.01$ & $88.10^{\mathrm{a}} \pm 0.03$ \\
SF50:CF50 & $1.66^{\mathrm{f}} \pm 0.01$ & $3.08^{\mathrm{c}} \pm 0.01$ & $7.44^{\mathrm{d}} \pm 0.01$ & $1.13^{\mathrm{ab}} \pm 0.01$ & $12.23^{\mathrm{d}} \pm 0.01$ & $74.46^{\mathrm{d}} \pm 0.00$ \\
SF40:CF60 & $2.32^{\mathrm{d}} \pm 0.01$ & $2.84^{\mathrm{d}} \pm 0.01$ & $6.88^{\mathrm{e}} \pm 0.01$ & $1.12^{\mathrm{ab}} \pm 0.01$ & $11.29^{\mathrm{e}} \pm 0.01$ & $75.55^{\mathrm{c}} \pm 0.31$ \\
SF20:CF80 & $2.95^{\mathrm{b}} \pm 0.02$ & $2.34^{\mathrm{e}} \pm 0.01$ & $5.59^{\mathrm{f}} \pm 0.01$ & $1.17^{\mathrm{ab}} \pm 0.01$ & $4.95^{\mathrm{g}} \pm 0.01$ & $83.00^{\mathrm{b}} \pm 0.72$ \\
SF60:CF40 & $3.44^{\mathrm{a}} \pm 0.01$ & $3.61^{\mathrm{b}} \pm 0.01$ & $8.72^{\mathrm{c}} \pm 0.01$ & $1.14^{\mathrm{ab}} \pm 0.01$ & $19.24^{\mathrm{c}} \pm 0.01$ & $63.85^{\mathrm{e}} \pm 0.15$ \\
SF80:CF20 & $3.46^{\mathrm{a}} \pm 0.01$ & $3.91^{\mathrm{a}} \pm 0.01$ & $10.76^{\mathrm{a}} \pm 0.01$ & $1.14^{\mathrm{ab}} \pm 0.01$ & $20.07^{\mathrm{b}} \pm 0.01$ & $60.66^{\mathrm{f}} \pm 0.01$ \\
\hline
\end{tabular}

Values are means \pm standard deviation of duplicate determination. Mean values in the same column with different superscripts are significantly different $(\mathrm{p}<0.05)$. WF-Wheat flour, SF- Soybean flour, CF-Cassava flour. WF100 (100\% Wheat flour). SF100 (100\% soybean flour). CF100 (100\% cassava flour). SF50:CF50 ( $50 \%$ soybean flour: $50 \%$ cassava flour). SF40:CF60 (40\% soybean flour: $60 \%$ cassava flour). SF20:CF80 ( $20 \%$ soybean flour: $80 \%$ cassava flour). SF60:CF40 (60\% soybean flour: $40 \%$ cassava flour). SF80:CF20 ( $80 \%$ soybean flour: $20 \%$ cassava flour).

The ash content ranged from 1.63 to $3.91 \%$. WF100 (100\% wheat flour strip) had the lowest ash value while SF80:CF20 (80\% soybean flour: $20 \%$ cassava flour strip) had the highest value. Increase in the proportion of soybean flour resulted to increased ash content, suggesting the influence of legumes on the ash content of food formulation. Ash content is the fraction in biomass that is composed of incombustible mineral material, which is a representation of mineral availability in food (Mamiro et al., 2011). Soybean is rich in minerals (Rooney and Waniska, 2000), therefore the increased ash content of the strips containing soybean flour may suggest improved mineral content than in the strips containing $100 \%$ wheat or cassava flour.

The fat content of the soybean-cassava strips also increased significantly $(p<0.05)$ with increased soybean substitution (an oil seed) and ranged from 2.04 to $10.76 \%$. The fat content was highest in SF80:CF20 (80\% soybean flour: $20 \%$ cassava flour strip) formulation. Generally, the lipid content of the strips containing legumes is quite high which might result to decreased keeping quality as a result of increased susceptibility to rancidity (Ikujenlola et al., 2013). However, the strips containing legumes may have the capability of serving as a viable vehicle for fat soluble vitamins as well as improved mouth-feel and palatability (Coppin and Pike, 2011).
Fibre content ranged from 0.18 to $1.37 \%$. The fibre content of the reference sample was lower than the composite samples, reflecting the beneficial importance of complementation. However, the fibre content of the composite samples did not differ significantly ( $p \geq 0.05$ ). Fibre has been reported to offer a variety of health benefits and is essential in reducing the risk of chronic diseases such as diabetes, obesity, cardiovascular diseases and diverticulitis (Ajani et al., 2012). The low values obtained in this study may imply that, the strips produced from cassava and soybean flours might not contribute significantly to the dietary fibre needs of the human body.

Protein content ranged from 4.07 to $24.16 \%$. There was appreciably increase in the protein content of the strips as the proportion of soybean flour increased in the composite strips such that, SF80:CF20 (80 \% soybean flour: 20 $\%$ cassava flour strip) had the highest value (20.07\%) among the composite strips as expected. Thus, the increased protein content of the strips could be attributed to the influence of the soybean flour. Ndife et al. (2011) reported an increase in protein content of bread as a result of partial substitution of wheat flour with soybean flour while flour Mashayekh et al. (2008) reported an increase in protein content of snack (cookies) as a result of soybean flour addition. About 23-56 g protein was recommended by $\mathrm{FAO} / \mathrm{WHO} / \mathrm{UNU}$ (1994) to meet the protein needs of the human body and combat protein deficiency. The protein content 
suggested that the strips might be valuable in combating protein energy malnutrition.

The carbohydrate content of the soybeancassava strips ranged from 60.46 to $88.10 \%$ and was observed to decrease with increased soybean flour substitution. The values were higher than 33.35 to $54.27 \%$ reported by Ndife et al. (2011) for wheat-soybean bread. Oguntona et al. (1987), reported that food products from cassava are energy-rich foods which is in agreement with the findings of this study.

\section{Vitamin composition}

Table 3 showed the vitamin composition of the soybean-cassava strips. The pro-vitamin A content ranged from 0.45 to $3.83 \mu \mathrm{g} / 100 \mathrm{~g}$ with significant differences existing among the samples. WF100 (100\% wheat flour strip) and SF80:CF20 (80 \% soybean flour: $20 \%$ cassava flour strip) had the lowest and highest provitamin A values respectively. It was also observed that the vitamin value of the formulated samples decreased with increased cassava flour substitution. Pro-Vitamin $A$ is important for sight functions (Akuyili et al., 2013). The pro-vitamin A content obtained in this study are below the recommended daily intake of $700-1000 \mu \mathrm{g} /$ day for men and $600-$ $800 \mu \mathrm{g} /$ day for women (FAO/WHO, 1998) which suggested that the formulated samples might not contribute significantly to eye health.

The vitamin $B_{1}$ composition of the strips ranged between 0.03 to $0.06 \mathrm{mg} / 100 \mathrm{~g}$. No significant differences ( $p \geq 0.05$ ) existing among the formulated samples (composite strips). The values are lower than the value $(0.25 \mathrm{mg} / 100 \mathrm{~g})$ reported by Suresh et al. (2015) for cassavawheat composite bread and below the recommended daily nutrient intakes of vitamin $\mathrm{B}_{1}$ for infants, children, and adults $(0.2-0.9,1.1$ $1.2,1.1-1.5 \mathrm{mg} /$ day) (FAO/WHO, 1998).

The results of vitamin $B_{2}$ (riboflavin) varied significantly $(p<0.05)$ among the samples with values ranging from 0.16 to $0.63 \mathrm{mg} / 100 \mathrm{~g}$. SF20:CF80 had the highest value while SF80:CF20 had the lowest value. The cassava flour had more influence on the vitamin $B_{2}$ content than the soybean flour, the composite strips containing higher proportion of cassava flour had higher vitamin $B_{2}$ content.
However, the values obtained in this study are generally low and were below the FAO/WHO recommended daily intake (RDI) for adolescents and adults (1.00 to $1.30 \mathrm{mg} /$ day), pregnant women $(1.40 \mathrm{mg} /$ day $)$ and lactating women ( $1.60 \mathrm{mg} /$ day) but within the RDI for infants and children ( 0.30 to $0.90 \mathrm{mg} / \mathrm{day}$ ).

The result of vitamin $B_{3}$ content of the strips ranged from 0.27 to $1.51 \mathrm{mg} / 100 \mathrm{~g}$ with SF100 (100\% soybean flour strip) and CF100 (100\% cassava flour strip) having the highest vitamin $B_{3}$ values respectively. The formulation of composite strips had a positive influence on vitamin $\mathrm{B}_{3}$ compared to the reference sample but the values were below the FAO/WHO recommended daily intake for infants and children (2.00 to $12.00 \mathrm{mg} /$ day), adults (14.00 to $16.00 \mathrm{mg} /$ day), pregnant women (18.00 $\mathrm{mg} /$ day) and lactating women (17.00 mg/day).

The vitamin $\mathrm{C}$ content of the strips ranged between 1.33 to $2.71 \mathrm{mg} / 100 \mathrm{~g}$. The reference sample had lower values than the composite strips which implied that the blending of soybean and cassava flours had beneficial impact on the vitamin $\mathrm{C}$ level of the strips. Increasing soybean flour proportion resulted to an increase in the vitamin $C$ content of the samples. The result obtained in this study was below the value (3.67 $\mathrm{mg} / 100 \mathrm{~g}$ ) reported by Jitngarmkusol et al. (2008) for cassava strips. Also, the vitamin C values obtained in this study were below the FAO/WHO recommended daily intake for infants and children ( 25.00 to $35.00 \mathrm{mg} /$ day), adults (40.00 to $45.00 \mathrm{mg} /$ day), pregnant women (55.00 mg/day) and lactating women (70.00 $\mathrm{mg} /$ day) (FAO/WHO, 1998).

\section{Mineral content}

Mineral contents of the strips are shown in Table 4. The calcium content of the strips ranged from 1.01 to $5.83 \mathrm{mg} / 100 \mathrm{~g}$. The calcium content increased with increased proportion of soybean flour. The values obtained suggested that the consumption of every $100 \mathrm{~g}$ of the strips would result to calcium intake that is below the FAO/WHO recommended daily intake for calcium of different target consumer such as Infants and children of 0 to 9 years ( 300 to $700 \mathrm{mg} /$ day), Adolescents of 10 to 18 years $(1300 \mathrm{mg} /$ day), 
Table 3: Vitamin composition of soybean-cassava strips.

\begin{tabular}{lccccc}
\hline Sample & $\begin{array}{c}\text { pro-Vitamin A } \\
(\mu \mathrm{g} / 100 \mathrm{~g})\end{array}$ & $\begin{array}{c}\text { Vitamin B } \\
(\mathrm{mg} / 100 \mathrm{~g})\end{array}$ & $\begin{array}{c}\text { Vitamin } \mathrm{B}_{2} \\
(\mathrm{mg} / 100 \mathrm{~g})\end{array}$ & $\begin{array}{c}\text { Vitamin B } \\
(\mathrm{mg} / 100 \mathrm{~g})\end{array}$ & $\begin{array}{c}\text { Vitamin C } \\
(\mathrm{mg} / 100 \mathrm{~g})\end{array}$ \\
\hline WF100 & $0.45^{\mathrm{g}} \pm 0.01$ & $0.06^{\mathrm{a}} \pm 0.00$ & $0.53^{\mathrm{b}} \pm 0.01$ & $0.34^{\mathrm{e}} \pm 0.01$ & $1.33^{\mathrm{de}} \pm 0.01$ \\
SF100 & $3.17^{\mathrm{b}} \pm 0.01$ & $0.03^{\mathrm{d}} \pm 0.00$ & $0.47^{\mathrm{c}} \pm 0.01$ & $0.27^{\mathrm{f}} \pm 0.01$ & $2.56^{\mathrm{ab}} \pm 0.01$ \\
CF100 & $2.50^{\mathrm{d}} \pm 0.01$ & $0.05^{\mathrm{b}} \pm 0.00$ & $0.52^{\mathrm{b}} \pm 0.01$ & $1.51^{\mathrm{a}} \pm 0.00$ & $1.51^{\mathrm{d}} \pm 0.01$ \\
SF50:CF50 & $2.51^{\mathrm{d}} \pm 0.01$ & $0.04^{\mathrm{cd}} \pm 0.00$ & $0.43^{\mathrm{c}} \pm 0.01$ & $0.93^{\mathrm{b}} \pm 0.00$ & $1.86^{\mathrm{c}} \pm 0.01$ \\
SF40:CF60 & $2.40^{\mathrm{e}} \pm 0.01$ & $0.04^{\mathrm{cd}} \pm 0.00$ & $0.55^{\mathrm{b}} \pm 0.01$ & $0.74^{\mathrm{c}} \pm 0.01$ & $1.71^{\mathrm{cd}} \pm 0.01$ \\
SF20:CF80 & $1.94^{\mathrm{f}} \pm 0.01$ & $0.03^{\mathrm{d}} \pm 0.00$ & $0.63^{\mathrm{a}} \pm 0.01$ & $0.68^{\mathrm{d}} \pm 0.01$ & $1.64^{\mathrm{cd}} \pm 0.01$ \\
SF60:CF40 & $3.21^{\mathrm{c}} \pm 0.01$ & $0.03^{\mathrm{d}} \pm 0.00$ & $0.25^{\mathrm{d}} \pm 0.01$ & $0.68^{\mathrm{d}} \pm 0.01$ & $2.37^{\mathrm{b}} \pm 0.01$ \\
SF80:CF20 & $3.83^{\mathrm{a}} \pm 0.01$ & $0.04^{\mathrm{cd}} \pm 0.00$ & $0.16^{\mathrm{e}} \pm 0.01$ & $0.72^{\mathrm{c}} \pm 0.01$ & $2.71 \mathrm{~b}^{\mathrm{a}} \pm 0.01$
\end{tabular}

Values are means + standard deviation of duplicate determination. Mean values in the same column with different superscripts are significantly different $(p<0.05)$. WF-Wheat flour, SF- Soybean flour, CF-Cassava flour. WF100 (100\% Wheat flour). SF100 (100\% soybean flour). CF100 (100\% cassava flour). SF50:CF50 ( $50 \%$ soybean flour: $50 \%$ cassava flour). SF40:CF60 ( $40 \%$ soybean flour: $60 \%$ cassava flour). SF20:CF80 ( $20 \%$ soybean flour: $80 \%$ cassava flour). SF60:CF40 (60\% soybean flour: $40 \%$ cassava flour). SF80:CF20 ( $80 \%$ soybean flour: $20 \%$ cassava flour).

adults of $19+$ years (1000 to $1300 \mathrm{mg} /$ day), pregnant women (1200 mg/day) and lactating women (1000 mg/day) (FAO/WHO, 1998). Calcium promotes bone formation, contraction of the muscles and assists in blood clotting. Although, the composite strips had improved calcium contents which are below the FAO/WHO recommended daily intake and might possibly not provide the needed calcium for body needs.

The magnesium content of the strips ranged from 1.35 to $42.60 \mathrm{mg} / 100 \mathrm{~g}$. The magnesium content of the composite strips increased as the proportion of soybean flour increases. However, the values obtained are below the recommended nutrient intake for infants and children (26 to $100 \mathrm{mg} /$ day), adolescents (230 mg/day for females and $220 \mathrm{mg} /$ day for males) and adults (220 mg/day for females and $260 \mathrm{mg} /$ day for males) respectively (FAO/WHO, 1998). The magnesium content of the strips may not be adequate to satisfy the daily functions in the human body due to their inability to reach the recommended daily allowance.

Phosphorus content ranged from 1.16 to 27.40 $\mathrm{mg} / 100 \mathrm{~g}$. SF100 (100\% soybean flour strip) had the highest phosphorus value $(27.40 \mathrm{mg} / 100 \mathrm{~g}$ ) while CF100 (100\% cassava flour strip) had the lowest value. The phosphorous content of the composite strips was higher than the reference sample $(3.13 \mathrm{mg} / 100 \mathrm{~g})$ which suggested an improvement after blending except for SF40:CF60 ( $40 \%$ soybean flour: $60 \%$ cassava flour) with a value $1.16 \mathrm{mg} / 100 \mathrm{~g}$. The phosphorus content of the strips increased with increased soybean flour substitution. The increased phosphorous content implied that the mineral content of snacks might be improved by developing composite products.

The sodium content of the strips ranged from 0.25 to $6.53 \mathrm{mg} / 100 \mathrm{~g}$. The composite strips had lower sodium content than the reference sample, thus, the production of strips from soybean and cassava flours resulted into product with lower sodium content. Low sodium content is beneficial to health especially in the aspect of blood pressure regulation (Onwuka, 2018). The low sodium content of the strips is therefore advantageous.

Potassium content ranged from 0.22 to 2.64 $\mathrm{mg} / 100 \mathrm{~g}$ which was lower than the value obtained for the reference sample $(100 \%$ wheat flour strip) (2.64 mg/100g). Gerlin et al. (2007) reported that potassium plays a key role in skeletal and smooth muscle contraction. The values suggested that the potassium content of the studied samples are quite low and might not be good sources of potassium. 
Table 4: Mineral composition of soybean-cassava strips (mg/100g).

\begin{tabular}{llllllll}
\hline Samples & Calcium & Magnesium & Phosphorus & Sodium & Potassium & Iron & Zinc \\
\hline WF100 & $5.83^{\mathrm{a}} \pm 0.01$ & $7.14^{\mathrm{e}} \pm 0.01$ & $3.13^{\mathrm{f}} \pm 0.14$ & $6.53^{\mathrm{a}} \pm 0.14$ & $2.64^{\mathrm{a}} \pm 0.14$ & $3.02^{\mathrm{a}} \pm 0.14$ & $0.24^{\mathrm{f}} \pm 0.01$ \\
SF100 & $4.62^{\mathrm{b}} \pm 0.01$ & $42.60^{\mathrm{a}} \pm 0.01$ & $27.40^{\mathrm{a}} \pm 0.14$ & $2.14^{\mathrm{b}} \pm 0.14$ & $0.17^{\mathrm{e}} \pm 0.14$ & $0.13^{\mathrm{e}} \pm 0.14$ & $2.54^{\mathrm{a}} \pm 0.01$ \\
CF100 & $1.01^{\mathrm{h}} \pm 0.01$ & $1.35^{\mathrm{f}} \pm 0.01$ & $1.20^{\mathrm{g}} \pm 0.01$ & $0.25^{\mathrm{f}} \pm 0.14$ & $0.35 \mathrm{C}^{\mathrm{d}} \pm 0.14$ & $0.16^{\mathrm{e}} \pm 0.14$ & $0.03^{\mathrm{g}} \pm 0.01$ \\
SF50:CF50 & $3.11^{\mathrm{e}} \pm 0.14$ & $20.40^{\mathrm{c}} \pm 0.01$ & $15.40^{\mathrm{c}} \pm 0.01$ & $1.16^{\mathrm{c}} \pm 0.14$ & $0.27^{\mathrm{ed}} \pm 0.14$ & $1.53^{\mathrm{b}} \pm 0.2$ & $1.27^{\mathrm{b}} \pm 0.01$ \\
SF40:CF60 & $2.16^{\mathrm{g}} \pm 0.14$ & $15.05^{\mathrm{d}} \pm 0.01$ & $1.16^{\mathrm{g}} \pm 0.01$ & $0.26^{\mathrm{f}} \pm 0.14$ & $1.43^{\mathrm{b}} \pm 0.01$ & $1.26^{\mathrm{d}} \pm 0.01$ & $1.06^{\mathrm{e}} \pm 0.01$ \\
SF20:CF80 & $2.27^{\mathrm{f}} \pm 0.14$ & $14.55^{\mathrm{d}} \pm 0.01$ & $11.95^{\mathrm{e}} \pm 0.14$ & $0.89^{\mathrm{e}} \pm 0.01$ & $0.22^{\mathrm{ed}^{\mathrm{d}}} \pm 0.71$ & $1.41^{\mathrm{c}} \pm 0.01$ & $1.21^{\mathrm{d}} \pm 0.01$ \\
SF60:CF40 & $3.35^{\mathrm{d}} \pm 0.01$ & $15.10^{\mathrm{d}} \pm 0.01$ & $13.15^{\mathrm{d}} \pm 0.14$ & $1.04^{\mathrm{d}} \pm 0.14$ & $0.24^{\text {ed }} \pm 0.01$ & $1.42^{\mathrm{c}} \pm 0.01$ & $1.24^{\mathrm{c}} \pm 0.01$ \\
SF80:CF20 & $3.71^{\mathrm{c}} \pm 0.01$ & $22.35^{\mathrm{b}} \pm 0.01$ & $18.35^{\mathrm{b}} \pm 0.01$ & $1.13^{\mathrm{c}} \pm 0.14$ & $0.42^{\mathrm{c}} \pm 0.14$ & $1.51^{\mathrm{b}} \pm 0.01$ & $1.29^{\mathrm{b}} \pm 0.01$ \\
\hline
\end{tabular}

Values are means \pm standard deviation of duplicate determination. Mean values in the same column with different superscripts are significantly different ( $p<0.05)$. WF100 (100\% Wheat flour). SF100 (100\% soybean flour). CF100 ( $100 \%$ cassava flour). SF50:CF50 ( $50 \%$ soybean flour: $50 \%$ cassava flour). SF40:CF60 ( $40 \%$ soybean flour: $60 \%$ cassava flour). SF20:CF80 ( $20 \%$ soybean flour: $80 \%$ cassava flour). SF60:CF40 (60\% soybean flour: $40 \%$ cassava flour). SF80:CF20 ( $80 \%$ soybean flour: $20 \%$ cassava flour).

The iron content of the strips ranged from 0.13 to $3.02 \mathrm{mg} / 100 \mathrm{~g}$. The reference sample $(100 \%$ wheat flour strip) had the highest iron value $(3.02 \mathrm{mg} / 100 \mathrm{~g}$ ) which implied that the development of composite strips from soybean and cassava flours did not improve the iron content of the final product. Iron deficiency anemia is a serious problem for certain at-risk groups (Food and Nutrition Board, Institute of Medicine, 2002) and continued research is ongoing for the development of snack with appreciable iron content. However, the iron content obtained in this study was below the recommended daily intake for a dietary iron bioavailability of $15 \%$ with respect to infants and children (5.90 to $6.20 \mathrm{mg} /$ day), adolescents (9.30 to $20.70 \mathrm{mg} /$ day for females and 9.70 to $12.5 \mathrm{mg} /$ day for males) and adults (19.60 $\mathrm{mg} /$ day for females and $9.10 \mathrm{mg} /$ day for males) respectively (FAO/WHO, 1998).

The zinc values of the strips ranged between 0.03 to $2.54 \mathrm{mg} / 100 \mathrm{~g}$. The addition of the soybean flour increased the zinc value of the samples, which is an important mineral for growth and development as reported by Chandra (2002). Tuber-based diets as well as cereals are deficient in iron and zinc which can be improved by the addition legumes (FAO/WHO, 1998) as observed in the present study. However, the zinc content of the formulated strips was below the recommended daily intake with respect to infants and children (6.60 to $11.20 \mathrm{mg} /$ day), adolescents (14.40 $\mathrm{mg} /$ day for females and $17.10 \mathrm{mg} /$ day for males) and adults $(9.80 \mathrm{mg} /$ day for females and
$14.00 \mathrm{mg} /$ day for males) respectively (FAO/WHO, 1998).

\section{Anti-nutrient composition}

The results of antinutrient composition of the soybean-cassava strips are shown in Table 5. Phytate content $(0.22$ to $5.59 \mathrm{mg} / 100 \mathrm{~g})$ was lower than $25 \mathrm{mg} / 100 \mathrm{~g}$, the amount considered lethal to health (Nagel, 2010). The formulated strips had higher phytate content than the reference sample ( $100 \%$ wheat flour strip). Increasing proportion of cassava flour resulted to increased phytate content in the strips. Phytate is often considered as an antinutrient because it binds minerals $\left(\mathrm{Zn}^{2+}, \mathrm{Fe}^{2+/ 3+}, \mathrm{Ca}^{2+}\right.$, $\mathrm{Mg}^{2+}, \mathrm{Mn}^{2+}$, and $\mathrm{Cu}^{2+}$ ) in the digestive tract, making them unavailable (Dick et al., 2018), and reduces mineral absorption thereby reducing bioavailability (Gupta et al., 2013).

The tannin content ranged from 0.34 to 4.13 $\mathrm{mg} / 100 \mathrm{~g}$. The reference sample had lower tannin content than the formulated strips. Increasing proportion of soybean flour resulted into increased tannin content in the strips. However, the tannin in the strips was generally below the reported lethal dose of $90 \mathrm{mg} / 100 \mathrm{~g}$ (Ifie and Emeruwa, 2011). Therefore, the tannin level in the strips might not influence digestion negatively since high tannin concentration impairs microbial enzyme activities including cellulose and intestinal digestion may be depressed (Ferrell and thorington, 2006).

The trypsin inhibitor for the reference sample was lower than the formulated sample with values ranging from 0.04 to $1.69 \mathrm{mg} / 100 \mathrm{~g}$. 
Trypsin inhibitors cleave with proteins thereby preventing the binding of protein and trypsin and affecting the digestion of protein (Aviles-
Gaxiola et al., 2018). However, the values obtained in this study are quite low and might not influence protein digestion negatively.

Table 5: Antinutrient composition of soybean-cassava strips (mg/100g)

\begin{tabular}{lllllc}
\hline Samples & Phytate & Tannin & $\begin{array}{l}\text { Trypsin } \\
\text { Inhibitor }\end{array}$ & Saponin & $\begin{array}{c}\text { Hydrogen } \\
\text { Cyanide }\end{array}$ \\
\hline WF100 & $0.22^{\mathrm{g}} \pm 0.01$ & $0.34^{\mathrm{f}} \pm 0.01$ & $0.04^{\mathrm{g}} \pm 0.01$ & $0.36^{\mathrm{a}} \pm 0.01$ & $0.06^{\mathrm{d}} \pm 0.01$ \\
SF100 & $1.31^{\mathrm{e}} \pm 0.01$ & $4.13^{\mathrm{a}} \pm 0.02$ & $1.69^{\mathrm{a}} \pm 0.01$ & $0.02^{\mathrm{d}} \pm 0.01$ & $0.00^{\mathrm{c}} \pm 0.01$ \\
CF100 & $5.31^{\mathrm{b}} \pm 0.01$ & $0.12^{\mathrm{g}} \pm 0.01$ & $0.54^{\mathrm{d}} \pm 0.01$ & $0.02^{\mathrm{d}} \pm 0.01$ & $2.11^{\mathrm{a}} \pm 0.01$ \\
SF50:CF50 & $5.33^{\mathrm{a}} \pm 0.02$ & $3.11^{\mathrm{b}} \pm 0.01$ & $0.67^{\mathrm{c}} \pm 0.02$ & $0.06^{\mathrm{c}} \pm 0.01$ & $0.87^{\mathrm{b}} \pm 0.01$ \\
SF40:CF60 & $3.59^{\mathrm{c}} \pm 0.02$ & $1.63^{\mathrm{d}} \pm 0.02$ & $0.25^{\mathrm{e}} \pm 0.01$ & $0.04^{\mathrm{d}} \pm 0.01$ & $0.97^{\mathrm{b}} \pm 0.01$ \\
SF20:CF80 & $5.59^{\mathrm{f}} \pm 0.01$ & $0.54^{\mathrm{e}} \pm 0.01$ & $0.16^{\mathrm{f}} \pm 0.01$ & $0.07^{\mathrm{c}} \pm 0.01$ & $1.14^{\mathrm{b}} \pm 0.01$ \\
SF60:CF40 & $2.15^{\mathrm{d}} \pm 0.01$ & $2.04^{\mathrm{c}} \pm 0.01$ & $0.91^{\mathrm{b}} \pm 0.01$ & $0.02^{\mathrm{b}} \pm 0.01$ & $0.57^{\mathrm{c}} \pm 0.01$ \\
SF80:CF20 & $2.15^{\mathrm{d}} \pm 0.0$ & $2.04^{\mathrm{c}} \pm 0.01$ & $0.89^{\mathrm{b}} \pm 0.01$ & $0.03^{\mathrm{b}} \pm 0.01$ & $0.14^{\mathrm{b}} \pm 0.08$
\end{tabular}

Values are means \pm standard deviation of duplicate determination. Mean values in the same column with different superscripts are significantly different $(p<0.05)$. WF100 (100\% Wheat flour). SF100 (100\% soybean flour). CF100 ( $100 \%$ cassava flour). SF50:CF50 ( $50 \%$ soybean flour: $50 \%$ cassava flour). SF40:CF60 (40\% soybean flour: $60 \%$ cassava flour). SF20:CF80 ( $20 \%$ soybean flour: $80 \%$ cassava flour). SF60:CF40 (60\% soybean flour: $40 \%$ cassava flour). SF80:CF20 ( $80 \%$ soybean flour: $20 \%$ cassava flour).

The saponin content of the reference sample was higher than the values obtained for the formulated samples with values ranging from 0.02 to $0.36 \mathrm{mg} / 100 \mathrm{~g}$. Saponin can form complexes with zinc and iron, thus, limiting their bioavailability (Sun et al., 2009). It has been reported that, consumption of $5-10 \mathrm{mg} / \mathrm{kg}$ of saponin produces local effect of corrosion and paralytic ileus (Joint FAO/WHO Expert Committee on Food Additives, 2005). From this study, the soybean-cassava strips contained low amount of saponin, and may possibly cause no health adverse effect.

The results of hydrogen cyanide ranged from 0.00 to $2.11 \mathrm{mg} / 100 \mathrm{~g}$. The results showed that hydrogen cyanide obtained in the formulated samples was solely contributed by the cassava flour since there was no hydrogen cyanide in SF100 (100\% soybean flour strip). Increasing proportion of cassava flour resulted into increased hydrogen cyanide content in the formulated strips. However, the hydrogen cyanide content of the strips was below the lethal those of $>10 \mathrm{mg} / \mathrm{kg}$ as stipulated by Codex Alimentarius Commission (2013).

\section{Sensory evaluation}

The sensory properties of soybean-cassava strips are presented in Table 6 . The appearance score of the samples ranged from 5.45 to 8.45 . The composite strips had higher appearance score than the control. Strips from $20 \%$ soybean flour: $80 \%$ cassava flour (SF20:CF80) was rated higher by the panelist than other strips. This could be due to the fact that the increasing addition of soybean caused the strips to turn darker than strips containing higher proportion of cassava flour. The browning could also be as a result of caramelization and mallard reactions, as the proteins contributed by soybean flour must have reacted with sugar during frying (Manzocco et al., 2011), thus, SF20:CF80 (20\% soybean flour: $80 \%$ cassava flour strip) with a score of 8 was liked very much by the panelist. Stripes from $50 \%$ soybean flour: $50 \%$ cassava flour (SF50:CF50) and SF40:CF60 (40\% soybean flour: $60 \%$ cassava flour strip) with a score of 7 was liked moderately by the panelists. SF80:CF20 (20\% soybean flour: $80 \%$ cassava flour strip) with a score of 5 was neither liked nor disliked. Crispiness ranged from 1.45 to 8.40. The composite samples had lower score than the control except SF20:CF80.

Among the formulated samples, SF20:CF80 (20 $\%$ soybean flour: $80 \%$ cassava flour strip) was liked very much with mean score of 7 by the panelist. Mouth feel ranged from 4.15 to 7.30. SF100 (100\% soybean flour strip), SF80:CF20 ( $80 \%$ soybean flour: $20 \%$ cassava flour strip) and SF60:CF40 (60\% soybean flour: $40 \%$ 
Table 6: Sensory properties of soybean-cassava strips.

\begin{tabular}{llllllll}
\hline Samples & Appearance & Crispiness & Mouthfeel & Texture & Taste & Flavour & $\begin{array}{l}\text { General } \\
\text { acceptability }\end{array}$ \\
\hline WF100 & $6.85^{\mathrm{cb}} \pm 1.71$ & $6.45^{\mathrm{a}} \pm 1.71$ & $6.40^{\mathrm{ab}} \pm 1.51$ & $4.10^{\mathrm{cd}} \pm 1.51$ & $6.30^{\mathrm{ab}} \pm 1.51$ & $6.25^{\mathrm{abc}} \pm 0.51$ & $6.45^{\mathrm{dcb}} \pm 0.51$ \\
SF100 & $5.65^{\mathrm{ab}} \pm 1.61$ & $4.55^{\mathrm{a}} \pm 0.51$ & $7.30^{\mathrm{a}} \pm 0.71$ & $5.25^{\mathrm{b}} \pm 1.61$ & $6.90^{\mathrm{a}} \pm 1.71$ & $7.25^{\mathrm{a}} \pm 1.61$ & $7.55^{\mathrm{ab}} \pm 1.61$ \\
CF100 & $7.95^{\mathrm{d}} \pm 0.51$ & $7.60^{\mathrm{c}} \pm 1.51$ & $6.20^{\mathrm{ab}} \pm 1.71$ & $5.55^{\mathrm{b}} \pm 1.71$ & $6.25^{\mathrm{ab}} \pm 1.61$ & $4.65^{\mathrm{ab}} \pm 2.51$ & $6.40^{\mathrm{dcb} \pm 0.71}$ \\
SF50:CF50 & $7.45^{\mathrm{cd}} \pm 1.71$ & $4.80^{\mathrm{c}} \pm 1.61$ & $5.65^{\mathrm{b}} \pm 1.51$ & $4.80^{\mathrm{cb}} \pm 1.81$ & $6.15^{\mathrm{ab}} \pm 1.81$ & $6.85^{\mathrm{cb}} \pm 1.81$ & $5.40^{\mathrm{d}} \pm 2.51$ \\
SF40:CF60 & $7.80^{\mathrm{ab}} \pm 1.71$ & $5.75^{\mathrm{a}} \pm 1.71$ & $6.30^{\mathrm{ab}} \pm 2.51$ & $5.25^{\mathrm{b}} \pm 1.61$ & $6.65^{\mathrm{ab}} \pm 1.61$ & $5.95^{\mathrm{ab}} \pm 1.61$ & $7.10^{\mathrm{ab}} \pm 1.81$ \\
SF20:CF80 & $8.45^{\mathrm{a}} \pm 1.71$ & $8.40^{\mathrm{a}} \pm 0.31$ & $4.15^{\mathrm{a}} \pm 1.71$ & $7.30^{\mathrm{a}} \pm 2.51$ & $7.15^{\mathrm{a}} \pm 1.91$ & $5.35^{\mathrm{a}} \pm 1.51$ & $7.70^{\mathrm{a}} \pm 1.61$ \\
SF60:CF40 & $6.00^{\mathrm{ab}} \pm 2.71$ & $5.35^{\mathrm{b}} \pm 0.51$ & $7.05^{\mathrm{a}} \pm 0.51$ & $5.75^{\mathrm{b}} \pm 1.61$ & $6.55^{\mathrm{ab}} \pm 1.41$ & $6.85^{\mathrm{ab}} \pm 1.71$ & $6.80^{\mathrm{abc} \pm 1.91}$ \\
SF80:CF20 & $5.45^{\mathrm{cd}} \pm 1.71$ & $2.80^{\mathrm{d}} \pm 0.51$ & $7.20^{\mathrm{b}} \pm 0.51$ & $3.20^{\mathrm{d}} \pm 1.71$ & $5.60^{\mathrm{b}} \pm 1.91$ & $7.25^{\mathrm{c}} \pm 1.81$ & $5.67^{\mathrm{cd}} \pm 0.51$ \\
\hline
\end{tabular}

Values are means \pm standard deviation of duplicate determination. Mean values in the same column with different superscripts are significantly different (p<0.05). WF100 (100\% Wheat flour). SF100 (100\% soybean flour). CF100 (100\% cassava flour). SF50:CF50 (50\% soybean flour: 50\% cassava flour). SF40:CF60 (40\% soybean flour: 60\% cassava flour). SF20:CF80 (20\% soybean flour: $80 \%$ cassava flour). SF60:CF40 (60\% soybean flour: $40 \%$ cassava flour). SF80:CF20 (80\% soybean flour: $20 \%$ cassava flour). 
cassava flour strip) with values of 7.30, 7.20 and 7.05 respectively was liked moderately by the panelist. The results showed that, increasing proportion of soybean flour resulted to improved mouthfeel. Texture ranged from 3.20 to 7.30 with SF20:CF80 (20\% soybean flour: $80 \%$ cassava flour strip) exhibiting better texture than the control sample as rated by the panelist and was liked moderately.

The improved texture associated with strips with higher proportion of cassava flour might be attributed to the cohesiveness of starch matrix present in cassava flour. Taste ranged from 5.60 to 7.15. The taste of composite samples was comparable to the control sample. The result showed that all the samples including the control were liked slightly by the panelist except SF20:CF80 (20\% soybean flour: $80 \%$ cassava flour strip) that was liked moderately and SF80:CF20 ( $80 \%$ soybean flour: $20 \%$ cassava flour strip) that was neither liked nor disliked by the panelist. The result for flavour showed that SF80:CF20 ( $80 \%$ soybean flour: $20 \%$ cassava flour strip) with a rating of 7.25 was rated higher by the panelist and it was not significantly different from SF100 (100\% soybean flour). The improved flavour in strips containing higher proportion of soybean flour could be attributed to the higher lipid and protein content of the flour. The results of general acceptability showed that SF20:CF80 (20\% soybean flour: $80 \%$ cassava flour strip) was best generally accepted among the soybean-cassava strips with a rating of 7.70 .

\section{Conclusion}

The findings of this study showed the applicability of soybean and cassava flours in the production of strips. The $100 \%$ wheat flour had better functional properties, however, increasing the proportion of soybean flour in the composites resulted to increased foam capacity, foam stability and oil absorption capacity but decreased water absorption capacity and gelatinization temperature. Strips produced from $80 \%$ soybean flour: $20 \%$ cassava flour blends had better proximate composition and sensory characteristics. The vitamin content was improved in the composite strips but were generally below the FAO/WHO recommended daily intakes. The mineral analysis showed that the reference sample had better mineral composition. However, the mineral contents of the samples were below the FAO/WHO recommended daily intakes. The antinutrient contents of the formulated samples exceeded those of the reference samples but were within the safe limit for consumption. It is therefore recommended that strips produced from soybean and cassava flours could be improved and optimized for the benefit of individuals with diabetes, celiac diseases, as well as protein energy malnutrition.

\section{References}

Achikanu, C. E., Eze-Steven, P. E., Ude, C. M. and Ugwuokolie, O. C. (2013). Determination of the vitamin and mineral composition of common leafy vegetables in south eastern Nigeria. Int. J. Current Microbio. Applied Sci. 2(11):347-353.

Adebowale, K.O. and Lawal, O. S. (2004). Comparative Study of the functional properties of Bambara groundnut (Voandzeia subterranean), Jack bean (Cana vliaensiformis) and Mucuna bean (Mucuna pruriens) flour. Fd. Resource Int. 37:355-365.

Adelakun, O. E., Duodu, K. G., Buys, E. and Olanipekun, B. F. (2013). Potential Use of Soybean Flour in Food Fortification. Intech, 513520.

Adejuyitan, J.A., Otunola, E. T., Akande, E. A., Bolarinwa, I. F. and Oladokun, F. (2009). Some physicochemical properties of flour obtained from fermentation of Tigernut (Cyperusesculentus). Fd. Sci. 3(2): 51- 055

Ajani, A. O., Oshundahunsi, O. F., Akinoso, R., Arowora, K. A., Abiodun, A. A. and Pessu, P. O. (2012). Proximate Composition and Sensory Qualities of Snacks Produced from Breadfruit Flour. Global J. Sci. Frontier Res. Biological Sci., 12(7): 56-65. Online ISSN: 2249-4626.

Akapata, M. I. and Akubor P. I. (1999). Chemical composition and selected functional properties of sweet orange (Citrus sinensis) seed flour. J. Plant Fd. Human Nutr. 54:353-362.

Akuyili, D.O., Igwe, S.A. and Ogbogu, C.E. (2013). Effects of garden egg on some visual functions of visually active Igbos of Nigeria. J. of Ethnopharmacology 4: 25-40. 
Alozie, Y. E. and Chinma, C. E. (2015). Proximate composition, physical and sensory properties of cake prepared from wheat and cocoyam flour. J. Fd. Res. 4(5): 181-188.

Aviles-Gaxiola, S., Chuck-Hernandez, C., and Serna Saldivar, S.O (2018). Inactivation methods of trypsin inhibitor in legumes: a review. J. Fd. Sci. 83 (1): 17-29. doi: $10.1111 / 1750-$ $\underline{3841.13985}$

Association of Official and Analytical Chemists (AOAC) (2010). Official Methods of Analysis. $18^{\text {th }}$ Edition., Association of Official Analytical Chemists, Official Method 2.210, Washington DC, USA.

Ayetigbo, O., Latif, S., Abass, A. and Muller, J. (2018). Comparing characteristics of root, flour and starch of biofortified yellow-flesh and whiteflesh cassava variants, and sustainability considerations: A Review. Sustainability, 10: 3089.

Bugusu, B. A., Campanella, O. and Hamaker, B. R. (2001). Improvement of sorghum-wheat composite dough rheological properties and bread making quality through zein addition. Journal of Cereal Chemistry 78(1): 31-35.

Butt, M. S. and Batool, R. (2010). Nutritional and functional properties of some promising legumes proteins isolates. Pakistan J. Nutr. 9(4):373-379. doi: 10.3923/pjn.2010.373.379.

Chandra, R. K. (2002). Nutrition and the immune system from birth to old age. Eur. J. Clin. Nutri. 56:73-76. PubMed.

Codex Alimentarius Commission (2013). Joint FAO/WHO Food Standards Programme, Codex Committee on Contaminants in Foods: Proposed Draft Maximum levels for Hydrogen Cyanide in cassava and cassava products; seventh session, Moscow, Russian Federation,1-34.

Coppin, E. A. and Pike, O. A. (2001). Oil stability index correlated with sensory determination of oxidative stability in light-exposed soybean oil. J. Amer. Oil Chem. Soc. 78(11): 13-18.

Dada, T. A., Barber, L. I., Ngoma, L. and Mwanza, M. (2017). Formulation, sensory evaluation, proximate composition and storage stability of cassava strips produced from composite flour of cassava and cowpea. Fd. Sci. Tech. 6: 395-399.

Dick, R. A., Zadrozny, K. K., Xu, C., Schur, F. K., Lyddon, T. D., Ricana, C. L., Wagner, J. M., Perilla, J. R., Ganser-Pornillos, B. K., Johnson, M. C., Pornillos, O. and Vogt, V. M. (2018). Inositol phosphates are assembly co-factors for HIV-1. Nature 560 (19): 509-

512.

El-Adawy T.A. (2001). Characteristics and Composition of watermelon, pumpkin and paprika seed oils and flours. J. Agric. Fd. Chem. 49:1253-1259.

Etiosa, O. R., Nnadozie, B. C. and Anuge, B. (2018). Mineral and proximate composition on of soybean. Asian J. Phys. Chem. Sci. 4(3): 1-6.

Ezeocha, V.C. and Onwuka, G. I. (2010). Effect of processing methods on the Physico-chemical and nutritional quality of maize and soybean based complimentary blends. Nig. Fd. J. 28 (2): 210-216.

FAO/WHO (1998). Vitamin and mineral requirements in human nutrition: report of a FAO/WHO expert consultation Bangkok, Thailand. $2^{\text {nd }}$ Edition. 1-362. ISBN 924154612 3.

FAO/WHO/UNU (1994). Energy and Protein Requirements. WHO Technical Report Series 724.ISSN: 0512-3034. Expert consultation, FAO Publications.

http://www.fao.org/clorep/003/aa04oe/AA040E0 1. Accessed on 23rd June, 2020.

Ferrell, K. E. and Thorington, R. W. (2006). Squirrels: the animal answer guide. Baltimore: Johns Hopkins University Press. 91. ISBN 978-08018-8402-3.

Food and Nutrition Board, Institute of Medicine, (2002). Dietary reference intakes for vitamin A, vitamin $\mathrm{K}$, arsenic, boron, chromium, copper, iodine, iron, manganese, molybdenum, nickel, silicon, vanadium, and zinc. Washington, DC: National Academy Press. 
Gerlin, J.R., Forster, S., Grafton, K.F., McClean, P.E. and Rojas-Cifuentes, G.A. (2007).

Analysis of seed zinc and other minerals in a recombinant inbred population of navy bean (Phaseolus vulgaris L.). Crop Science, 47:13611366.

Gupta, R. K., Gangoliya, S. S. and Singh, N. K. (2013). Reduction of phytic acid and enhancement of bioavailable micronutrients in food grains. J. Fd. Sci. Techn. 52 (2): 676-684. doi: $10.1007 / \mathrm{s} 13197-013-0978-y$

Hung, H. C., Joshipura, K. J. and Jiang, R. (2004). Fruit and vegetable intake and risk of major chronic disease. J. National Cancer Institute, 96:1577.

Ibeabuchi, J. C., Okafor, D. C., Peter, I. A., Agunwa, I. M., Eluchie, C. N. and Ofoedu, C. E. (2017). Cooperative study on the proximate composition, functional and sensory properties of the three varieties of Beans "Phaseolus tunatus", Phaseolus vulgaris" and "Vigna umbellatu". Int. J. Advancement of Eng. Techn. Mgt. Applied Science, 5(1):1-23.

Ifie, I. and Emeruwa, C. (2011). Nutritional and anti-nutritional characteristics of the larva of Oryctes monoceros. Agri. Bio. J. North America, (1992): 42-46.

http://doi.org/10.5251/abjna.2011.2.1.42.46

Ikujenlola, A.V., Oguntuase, S.O. and Omosuli, S.V. (2013). Physico-chemical Properties of complementary foods from malted quality protein maize and defatted fluted pumpkin flour. Food and Public Health, 3(6): 323-328.

Iwe, M. O. (2014). Current trends in sensory evaluation of foods. Revised Edition. Rojoint Communication Services Ltd. Uwani Enugu, Nigeria. Pp. 144-145.

Jitngarmkusol, S., Hongsuwankul, J. and Tananuwong, K. (2008). Chemical composition, functional Properties and microstructure of cassava strips. J. Fd. Chem. 110:23-30, doi:10.1016.

Joint FAO/WHO Expert Committee on Food Additives (2005). Sixty-fifth meeting Geneva, 7 16. Summary and Conclusions. http://www.who.int/ipcs/food/jecfa/summaries/s ummary65.pdf, accessed 14/1/2021.

Kaushal, P., Kumar, V. and Sharma, H. K. (2012). Comparative study of physico-chemical, functional, anti-nutritional and pasting properties of taro (Colocasia esculenta), rice (Oryza sativa), pegion pea (Cajanus cajan) flour and their blends. LWT-Fd. Sci. Techn. 48:59-68.

Kusuma, N. B. (2015). Soybean consumption and health benefits. Inter. J. Scientific and Techn. Res. 4(7): 50-53.

Kinsella, J. E., Damodaran, S. and German, B. (1985). Physicochemical and Functional Properties of Oil Seed Proteins with emphasis on Soy Proteins. In: new Protein Foods Alschul, A. M and H. L. Wilke (Eds) volume 5. New York, Academic Press, 107-179.

Mamiro, P. S., Mbwaga, A. M., Mamiro D. P., Mwanri A. W. and Kinabo, J. L. (2011). Nutritional quality and utilization of local and improved cowpea varieties in some regions in Tanzania. Afr. J. Fd. Agri. Nutr. Dev.11(5):44904506.

Manzocco, L., Calligaris, S., Mastrocola, D., Nicoli, M. and Lerici, C. (2011). Review of nonenzymatic browning and antioxidant capacity in processed food. Trends Fd. Sci. Techn. 11, 340-346.

Mashayekh, M., Mahmoodi, M. R., and Enterazzi, M. H. (2008). Effect of fortification of defatted soy flour on sensory and rheological properties of wheat bread. Int. J. Fd. Sci. Techn. 43: 16931698.

Mwasaru, M. A., Muhammad, K., Bakar, J., Yaakob, B. and Man, C. (1999). Effects of isolation technique and conditions on the extractability, physicochemical and functional properties of pigeon pea (Cajanus cajan) and cowpea (Vigna unguiculata) protein isolates. Physicochemical properties. Food Chem. 67: 435-444

Nagel, R. (2010). Living with Phytic Acid. Wise Traditions in Food, Farming and the Healing Arts, the quarterly journal of the Weston, 8-13 
Ndife, J., Abdulraheem, L. O and Zakari, U. M. (2011). Evaluation of the nutritional and sensory quality of functional breads produced from whole wheat and soya bean flour blends. African J. Fd. Sci. 5(8), Pp. 466-472.

Nwosu, J. N. (2011). The effects of processing on the antinutritional properties of moin-moin made from cowpea (Vigna unguiculata) and asparagus bean seed (Vigna sequipedalis). World Rural Observations, 3(3): 15.

Offor, C.E. (2015). Determination of vitamin composition of Dissotis rotundifolia leaves. Int. J. Curr. Microbiology and Applied Sci. 4(1): 211.

Oguntona, T., Bernstein, C. R., and Williams, L. (1987). Dietary (Nutrient) intake of Nigerian peasants living in a semi-arid zones. Ethiopian Journal of Health and Development, 2(1), 27-36.

O'Keefe, S., Bianchi, L. and Sharman, J. (2015). Soybean nutrition. SM J. Nutri. Metabolism, 1(1): 1-9.

Omosuli, S. V. (2014). Effects of processing on the chemical and anti-nutritional properties of cassava roots. Research and Reviews: Journal of Botanical Sciences, 3(2): 27-31.

Onimawo, A.I. and Akubor, P.I. (2005).

Functional properties of food. In: Food

Chemistry. Integrated approach with

Biochemical Background. Ambik Press

Limited, Benin City, Nigeria, 208-221.

Onimawo, A.I. and Egbekun, K.M. (1998). Comprehensive Food Science and Nutrition. (2nd ed.). ADMIK Press Ltd Benin. Pp. 193-201

Onwuka, G. I. (2018). Food Analysis and Instrumentation. Theory and practices. Naphtali Prints Lagos, Nigeria.

Onyenwoke, C. A. and Simonyan, K. J. (2014). Cassava post-harvest processing and storage in Nigeria: A review. Afri. J. Agri. Res. 2(1): 38543863.

Pele, G. I., Ogunsua, A. O., Adepeju, A. B., Esan, Y. O. and Oladiti, E. O. (2016). Effect of processing methods on the nutritional and antinutritional properties of soybeans. African J. Fd. Sci. Techn. 7(1): 9-12.

Rooney, L. W. and Waniska, R. D. (2000). Sorghum food and industrial utilization. 'Sorghum: Origin, History, Technology, and Production', John Wiley and Sons, New York.

Shittu, T. A., Raji, A. O. and Sanni, L. O. (2007). Bread from composite cassava-wheat flour:

Effect of baking time and temperature on some physical properties of bread loaf. Food Resource International 40:280-290.

Soetan, K. O., Olaiya, C. O., and Oyewole, O. E. (2010). The importance of mineral elements for humans, domestic animals and plants: A review. Afr. J. Fd. Sci. 4(5): 200-222.

SPSS (2018). Statistical package for the social sciences. Guild for personal computers, version 22.0 Edition, Chicago.

Sun, H., Xie, Yong. and Ye, Y. (2009). Advances in saponin-based adjuvants. Vaccine 27 (12): 1787-1796. doi:10.1016/j.vaccine.2009.01.091

Suresh, C., Samsher S., and Durvesh, K. (2015). Evaluation of the functional properties of composite flours and sensorial attributed of composite flour biscuits. J. Fd. Sci. Tech. 52(6): 3681-3688. 